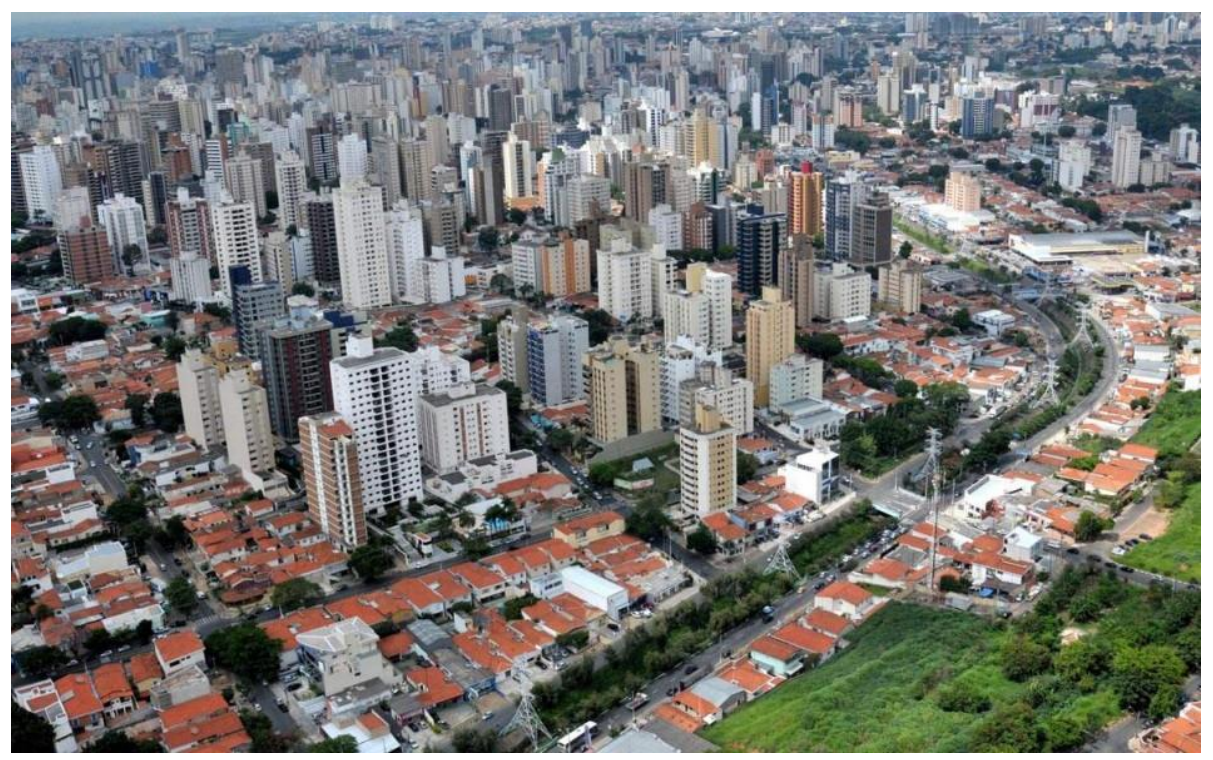

\title{
A urbanização de Campinas/SP e a produção de informação nas maiores ocupações da cidade
}

The urbanization of Campinas/SP and the information's production in the largest urban occupations

Resumo: Este artigo apresenta a urbanização corporativa de Campinas/SP no período contemporâneo através da análise da produção de informação, variável-chave na atualidade, do saber local e da densidade comunicacional. Para tal, analisamos a produção de informações descendentes, através das notícias do jornal local Correio Popular, sobre a maior ocupação urbana da cidade: a região do Jardim Campo Belo. Debatemos ainda a produção de informações ascendentes, produzidas no lugar e sobre o lugar, que ocorrem naquela ocupação e na região do Parque Oziel. Tratam-se das duas maiores ocupações de terras urbanas instaladas na cidade. Buscamos, assim, auxiliar na compreensão das periferias pobres urbanas brasileiras em meio ao processo de globalização.

Palavras-chave: urbanização corporativa, informação, saber local, densidade comunicacional, ocupações urbanas, Campinas/SP.

Abstract: This article presents the corporate urbanization in Campinas/SP in contemporary period by analyzing the production of information, key variable at present, the local knowledge and communication density. To this end, we analyze the production of descendents information, through the local newspaper Correio Popular News, on the largest urban occupation of the city: the Jardim Campo Belo region. Also discussed the production of ascending information produced in place and about the place, which occur in those occupation and the Parque Oziel region. These are the two major occupations of urban land located in the city. We seek to help in understanding the Brazilian urban poor neighborhoods in the middle of globalization.

Key-words: corporate urbanization, information, local knowledge, communication density, urban land occupations, Campinas/SP.

\footnotetext{
${ }^{1}$ Mestra em Geografia pelo Instituto de Geociências da Unicamp; bolsista de Apoio Técnico pelo CNPq do projeto de pesquisa "Círculos de informações e as dinâmicas do território brasileiro no período atual"; assistente de coordenação do Observatório Permanente dos Conflitos Urbanos de Campinas/SP ambos coordenados pela Profa. Dra. Adriana Maria Bernardes da Silva e realizados no GEOPLAN/IG/UNICAMP. Endereço postal: Rua João Pandiá Calógeras, 51, Cidade Universitária, Campinas/SP, CEP: 13083-870. Endereço eletrônico: helenarizzattifonseca@gmail.com
} 


\section{Introdução}

A cidade de Campinas/SP abriga diversas redes nacionais e globais de transporte e informação e, para isso, se reorganiza constantemente para incorporar a nova divisão territorial do trabalho, baseada na informação (LOJKINE, 1995), e se destaca como importante polo tecnológico nacional (SANTOS, 2000/IBGE, 2011). Ao mesmo tempo, a cidade conhece acentuada expansão da pobreza nas últimas décadas e acompanha, assim, o processo de urbanização brasileiro transformando-se numa metrópole corporativa e fragmentada (SOUZA, 2008). Nas palavras de Santos (2008 [1993], pp. 119 e 120)

Em primeiro lugar, o arranjo espacial das cidades muda, tanto pelo seu tamanho consideravelmente aumentado, como pela sua localização mais dispersa. Mudam, sobretudo, suas funções. As cidades são, de um lado, os elos de uma cooperação e de uma regulação que se devem dar em escala nacional, a serviço das atividades com dimensão nacional, isto é, as grandes empresas e o Estado. Por isso, devem ser localmente equipadas para o exercício dessa vocação 'nacional', indispensável à realização do modelo nacional adotado. As respectivas tarefas, consideradas menos relevantes [como a moradia da população de baixa renda], agregam-se, por necessidade funcional, mas de forma subordinada, às tarefas hegemônicas. A cidade se define segundo as modalidades dessas combinações dependentes do grau de desenvolvimento regional e da amplitude da respectiva divisão territorial do trabalho. As atividades não-hegemônicas são, em geral, deixadas à 'espontaneidade' do mercado. De um ponto de vista político, as atividades centrais, isto é, programadas como condição de êxito para o projeto nacional, são as que interessam ao próprio Estado e às corporações. Essas atividades centrais se dispõem em rede e sistema, interessando à totalidade dos núcleos urbanos, não importa onde estejam localizados. É nesse sentido que podemos falar de uma urbanização corporativa. (SANTOS, 2008 [1993], destaque do original, grifo da autora).

A manutenção da desigualdade socioespacial em Campinas é resultado da constante adaptação da cidade às exigências do sistema econômico capitalista, os interesses hegemônicos; e também da capacidade de organização e de resistência da população principalmente de baixa renda, os interesses não-hegemônicos, que, mesmo sem a devida intenção, acabam por criar novos usos do território ${ }^{2}$ ao construírem parte considerável da cidade através das ocupações de terras urbanas.

Consideramos essas ações não-hegemônicas como resistências, com base em Chauí (1987), e como contra-racionalidades do sistema econômico capitalista, com base em Santos (1996). A primeira autora explica que "Não nos referiremos às ações deliberadas de resistência [...], mas a práticas dotadas de uma lógica que as transforma

\footnotetext{
2 Tanto a ordem, quanto a contra-ordem constituem o 'território usado' (SANTOS \& SILVEIRA, 2001) e podem construir ações, saberes e normas que são ascendentes, por partir do lugar, e desalienadoras, por partir da reflexão crítica do cotidiano. A racionalidade e a contra-racionalidade constituem, então, as possibilidades de uso do território
} 
em atos de resistência" (CHAUÍ, 1987, p.63); enquanto as contra-racionalidades se tratam de novos usos dados aos objetos e ao uso do território pela população de baixa renda que, para sobreviver, precisa criar racionalidades paralelas ao sistema que se divergem e se convergem simultaneamente ${ }^{3}$.

As ocupações de terras urbanas, cada vez mais presentes nas metrópoles e grandes cidades do Brasil, a partir do início dos anos 1980 (RODRIGUES, 1988), são manifestações do processo de urbanização corporativa em andamento no país e da capacidade das contra-racionalidades e resistências orquestradas pelos agentes nãohegemônicos desse processo. Entendemos as ocupações urbanas como a rápida ação de construção de moradias, em terrenos privados e públicos dentro do perímetro urbano, pela população de baixa renda e possível devido a um planejamento prévio para escolha do local, do momento e da forma como ocorrerá a ocupação, assim como, para construí-la e para mantê-la possibilitando um novo uso do espaço urbano (idem). Esta forma de habitação na cidade se diferencia das favelas, pois estas costumam ocorrer de modo individual e mais lento com a chegada esparsa de famílias de baixa renda que constroem seus barracos para viver sem exigir um planejamento prévio da ação (idem). De acordo com estudo de Jacobi (1982, p.69)

\begin{abstract}
As invasões [ocupações de terra urbana] tocaram fundo nas raízes da sustentação do sistema econômico e político vigente, pois mexeram com a questão da propriedade privada, tornando aludível mudanças na legislação do uso da terra e colocaram em pauta dois temas contrapostos: o de direito à habitação e o do direito à propriedade. A visão clássica assegura ao proprietário o direito de usufruto da propriedade e sob essa ótica as ocupações representam violação grave. Entretanto, as inaceitáveis condições de vida dos pobres das cidades, que um sistema socialmente desigual não fez senão acentuar, modificam o enfoque da questão.
\end{abstract}

Hoje, Campinas está entre as quinze cidades brasileiras com maior número absoluto de população residente em favelas e ocupações (IBGE, 2011). Configura-se um espaço urbano que abriga as modernizações, mas incapaz de responder às necessidades de grande parte da sua população e, desse modo, reprodutor de uma pobreza estrutural (SANTOS, 2000b). Essa desigualdade socioespacial permite compreender a existência de

\footnotetext{
${ }^{3}$ Nas palavras de Santos (1996, p. 246) "Essas contra-racionalidades se localizam, de um ponto de vista social, entre os pobres, os migrantes, os excluídos, as minorias; de um ponto de vista econômico, entre as atividades marginais, tradicional ou recentemente marginalizadas; e, de um ponto de vista geográfico, nas áreas menos modernas e mais 'opacas', tornadas irracionais para usos hegemônicos. [...]. O que muitos consideram, adjetivamente, como 'irracionalidade' e, dialeticamente, como 'contra-racionalidade', constitui, na verdade, e substancialmente, outras formas de racionalidade, racionalidades paralelas, divergentes e convergentes ao mesmo tempo".
} 
espaços luminosos e espaços opacos nos quais não só a infraestrutura urbana e os problemas sociais demonstram essa desigualdade, como, também, as desigualdades do acesso à informação nas diferentes parcelas da cidade. De acordo com Santos \& Silveira (2001, p. 264) consideramos que "espaços luminosos [são] aqueles que mais acumulam densidades técnicas e informacionais, ficando mais aptos a atrair atividades com maior conteúdo em capital, tecnologia e organização"; por sua vez nos espaços opacos essas características estão ausentes havendo uma gama de situações entre esses dois extremos.

A informação, nessa análise, é considerada uma variável-chave do atual período histórico, denominado por Santos (1999), como período técnico-científico-informacional. Nesse contexto da urbanização mundial é possível distinguir a existência de círculos de informações destinadas à produção e de círculos de informações banais, associadas ao cotidiano $^{4}$; ambas informações são em larga medida manipuladas por grandes empresas, porém, a segunda é menos restrita e se capilariza no território (SILVA, 2001). Nesse universo de informações banais podemos, por exemplo, destacar a produção e a veiculação de notícias, monopolizadas por grandes grupos de comunicação e associadas ao consumo e à indústria cultural. São informações hierárquicas, que atingem verticalmente os lugares e, por isso, conforme Santos (2000b), seriam informações descendentes. Mas, entre as informações banais também se destaca uma pluralidade de meios e agentes (antigos e novos) que organizam informações políticas, econômicas, culturais, ao lazer, entre outras, mais destinadas à construção da cidadania, à produção de um sentido político-cultural (idem). Tratar-se-iam de dinamismos mais arraigados ao lugar, ao dilema da sobrevivência, da resistência e da reprodução e constituiriam informações ascendentes. Esses círculos de informação se misturam, trazem novos conteúdos ao espaço geográfico, tornado campo de conflitos entre forças descendentes e ascendentes (idem).

De acordo com Santos (1999, pp. 21 e 22) “o saber local, que é nutrido pelo cotidiano, é a ponte para a produção de uma política, (...) o cotidiano é a realização das pessoas e, quem sabe, também das instituições e das empresas nos lugares”. Em contrapartida "na ação hegemônica predominam o pensamento operacional e pragmático, assim como, a redução dos ideários democráticos aos ritos formais da política”, como

\footnotetext{
${ }^{4}$ De acordo com Lefebvre (1980, p. 250) "O quotidiano possui o privilégio de arcar com o fardo mais pesado. Se o poder ocupa o espaço que gera, o quotidiano é solo sobre que se erigem as grandes arquiteturas da política e da sociedade”. De acordo com Santos (1999, p. 17) “o espaço teria uma quinta dimensão, a do cotidiano, que permitiria exatamente chegar à ideia de ação comunicacional”.
} 
escreve Ribeiro (2004, p. 42). Essa autora esclarece também que (idem, pp. 45 e 44) "o lugar é o cotidiano mas, é, ao mesmo tempo, os futuros nele contido. (...) lugar e saber encontram-se implicados nos projetos que visem à territorialidade cidadã, resistente à alienação territorial originada da apropriação antidemocrática de recursos" (destaques do original).

Com base nisso, afirmamos que a produção de informações ascendentes é uma possibilidade de resistência às mazelas causadas pela desigualdade socioespacial, inclusive à desigual distribuição das informações no território. Constituem o que chamamos de densidade comunicacional que faz referência ao "tempo plural do cotidiano partilhado, é o tempo conflitual da co-presença" (SANTOS, 1996, p. 203). Ao se comunicar e ao produzir informações sobre o lugar e para o lugar onde moram, os pobres trocam saberes e conhecimentos que podem permitir uma melhor compreensão do mundo e certa desalienação imbuída, em grande medida, pela realidade manipulada pelas grandes corporações da mídia.

Para esse artigo, pesquisamos a produção de informação descendente e ascendente nas duas maiores ocupações urbanas da cidade de Campinas, a região do Jardim Campo Belo e a região do Parque Oziel, numa área que delimitamos como Região Sul, uma parte da zona opaca da cidade. Ambas foram ocupadas no mês de fevereiro de 1997 e possuem, hoje, respectivamente, 50 mil e 30 mil pessoas aproximadamente (RIZZATTI, 2014). Distam dez quilômetros uma da outra sendo que a ocupação do Parque Oziel fica a cinco quilômetros do centro de Campinas e a do Jardim Campo Belo se localiza no limite Sul da cidade, a 15 quilômetros do centro, próxima ao Aeroporto Internacional de Viracopos.

Acompanhamos as informações descendentes produzidas pelo principal jornal ${ }^{5} \mathrm{da}$ cidade de Campinas, o Correio Popular, veiculado pela Rede Anhanguera de Comunicação $(\mathrm{RAC})^{6}$, e notamos como as notícias são carregadas de intenções hegemônicas que impedem uma compreensão do lugar e suas desigualdades, e tendem a uma desumanização da população residente neste local. Essa constatação foi possível através do acompanhamento de todas as notícias publicadas por esse veículo de informação sobre a região do Jardim Campo Belo, desde o momento de sua ocupação

\footnotetext{
${ }^{5}$ A decisão pela análise de notícias de jornal se deve pela maior facilidade de sistematizar esse material e pela capacidade deste meio de 'transvalorizar' os acontecimentos do mundo, do país e dos lugares para a sociedade contemporânea (SODRÉ, 1996, p. 133).

${ }^{6}$ A escolha dessa Rede se deve a sua importância como produtor de informações para Campinas e toda a Região Metropolitana de Campinas, pois trata-se de um grupo empresarial proprietário dos maiores veículos de comunicação da Região, logo, controlador de grande parte da produção local e regional de informações (GARDINI, 2006).
} 
(FONSECA, 2011). Ao mesmo tempo, através da realização de trabalhos de campo, buscamos os jornais, as rádios e os pontos de acesso à internet existentes nas ocupações ${ }^{7}$ para saber como os moradores se organizaram para produzirem seus próprios meios de comunicação e informação e, nesse momento, ganha destaque a região do Parque Oziel onde há um jornal e uma rádio local que atingem a maior parte da periferia de Campinas se destacando como um veículo informacional nessas áreas.

Na primeira etapa do texto realizamos uma curta explanação sobre a compreensão teórica da informação, da comunicação, do saber e do conhecimento; na sequência analisamos a produção de informação descendente com ênfase nos conflitos vividos na região do Jardim Campo Belo com interesses nacionais em jogo, devido à necessidade de expansão do Aeroporto Internacional de Viracopos que exigia a remoção da população dessa ocupação; e, por fim, analisamos a produção de informação ascendente existente nas duas regiões estudadas.

\section{Informação e comunicação no período contemporâneo: uma síntese}

Para compreendermos a produção e a difusão da informação na atualidade faz-se necessário abordar o que é a informação, o conhecimento, o saber e a comunicação. Todas essas dimensões-conceitos só existem na realidade de forma híbrida, sendo o isolamento delas um recurso analítico para tentarmos entender seus desdobramentos na realidade.

Podemos considerar que "o conhecimento é o resultado de um aprendizado social, pois que ele é antes de tudo conhecimento das determinações socialmente constituídas" (GORZ, 2005, p. 79). O saber, por sua vez, está mais relacionado com a capacidade de cada um de aprender a partir das situações do cotidiano. De acordo com Gorz (2005, p. 12), o saber é composto pela "atividade social que constrói relações comunicativas, não submetidas a um comando". Nota-se, então, uma diferença essencial entre os saberes e os conhecimentos: enquanto estes últimos podem se voltar a atender à ação hegemônica, os saberes valorizam e provém do cotidiano e respondem às necessidades que nele surgem, sendo, muitas vezes, uma maneira de resistir às ordens vindas de fora do lugar (SANTOS, 1996).

\footnotetext{
${ }^{7}$ Toda a área ao sul da Rodovia Anhanguera em Campinas, ou seja, toda a zona opaca da cidade, só possui acesso à internet através de rádio. Trata-se de uma maneira precária de acesso, pois a velocidade é muito reduzida e a manutenção da comunicação é instável, posto que a transmissão é feita através do espectro eletromagnético, meio que possui muitas interferências na comunicação. É por esse espectro que é realizada a transmissão de rádio no Brasil, até o momento. Em comparação à banda larga, instalada em toda a parcela ao norte da Via Anhanguera, em Campinas, que utiliza as fibras óticas para a conexão com o meio virtual realizado, assim, com maior velocidade e qualidade do que a conexão via rádio.
} 
A comunicação, de acordo com Raffestin (1993), acontece por meios interpessoais e informais, considerados meios de grande valor, por serem capazes de criar novos conteúdos no espaço geográfico, dificilmente controlado. Já para Santos (1996), comunicar é o ato de colocar em comum e, para tanto, se faz necessário que os indivíduos compartilhem experiências, vivam cotidianos parecidos, logo, a comunicação necessita de um território contíguo, assim como, a densidade comunicacional. Segundo o autor supracitado a análise das densidades técnica, informacional e comunicacional podem ser essenciais para compreender grandes cidades e metrópoles da periferia do sistema mundo autal. As duas primeiras são compreendidas como os diversos graus de artifício e de exterioridade, enquanto a densidade comunicacional refere-se ao "tempo plural do cotidiano partilhado, é o tempo conflitual da co-presença” (idem, p. 203). Como aponta Alves (2010, p. 07) em estudo sobre o circuito fonográfico de Campinas, "Da comunicação entre os indivíduos, acreditamos emergir formas de pensar e agir no território a partir de um projeto alternativo à racionalidade hegemônica. A informação e a comunicação têm capacidade de ordenação social, (...) ou seja, são entes de fundamental importância no contexto urbano contemporâneo". E a produção de informações em jornais locais e rádios comunitárias ou livres é uma demonstração da importância da comunicação e da informação no uso do território.

Por outro lado, de acordo com Gonçalvez (1994), “o conceito de informação pressupõe um estado de consciência sobre fatos ou dados", ou seja, a partir do dado ou fato bruto constrói-se um entendimento do mesmo. Como esclarece Mattelard (2005), para informar é necessário a instalação das tecnologias da informação, ou seja, de canais que permitam a transmissão da informação, sem a necessidade da existência de laços em comum entre os indivíduos, e possível de ser controlada sua difusão. Ainda sobre a questão, Santos escreve que

\footnotetext{
A informação é privilégio do aparelho do Estado e dos grupos econômicos hegemônicos, constituindo uma estrutura piramidal. No topo, ficam os que podem captar as informações, orientá-las a um centro coletor, que as seleciona, organiza e redistribui em função do seu interesse próprio. Para os demais não há, praticamente, caminho de ida e volta. São apenas receptores, sobretudo os menos capazes de decifrar os sinais e os códigos com que a mídia trabalha (SANTOS, 2000a [1987], p. 127).
}

Segundo Dantas (2003), até pouco mais de 1950, uma boa parte desse capitalinformação era tratada, de forma geral, "como recurso, ou bem público" (idem, p. 28, grifo do original). De modo semelhante, os meios de difusão da informação 
(telecomunicação e radiodifusão) "eram igualmente considerados infraestrutura de natureza pública, sendo diretamente controlados pelo Estado" (ibidem, grifo do original), pois sabia-se já que o controle dessa informação por alguns agentes impediria uma alocação 'ótima' de investimento e gasto para o consumo, sendo prejudicial ao próprio mercado a desigualdade de acesso a tal recurso. Nas palavras de Mattelard (2005, p. 15) "A informação e o saber são cada vez mais tratados como um bem imaterial e apropriável". Esse autor afirma ainda que, apesar de tecnicamente termos capacidade de atingir uma globalização solidária "a distância permanece enorme entre as capacidades virtuais da técnica e a exequibilidade geopolítico-econômica de sua mobilização, a serviço da luta contra as desigualdades sociais" (MATTELARD, 2005, p. 4). E quando analisamos as diversas parcelas da cidade de Campinas, sua desigualdade socioespacial, fica nítida essa diferenciação da distribuição técnica capaz de receber informações, ou seja, do meio técnico-científico-informacional ${ }^{8}$.

Lojkine (1995) também nos atenta para a importância da partilha da informação por toda a sociedade e considera sua concentração uma perversidade para com a sociedade mundial. $\mathrm{O}$ autor diz que

é preciso (...) reconhecer a gravidade da situação que, hoje, opõe os detentores quase exclusivos de informações estratégicas, as poucas metrópoles que concentram os grandes centros de pesquisa e de formação, à massa dos países, onde ainda impera o analfabetismo e que se arriscam a ser excluídos das economias da informação (...) o desafio central [em escala mundial] da revolução informacional: a partilha da informação, da qual a apropriação privada e o monopólio social são também uma fonte de ineficácia e de paralisia mesmo para aqueles que a monopolizam. (...). Os serviços informacionais não estão isolados na esfera do material - ao contrário, requisitam suportes físicos, verdadeiros meios de consumo coletivos, que remetem a um consumo que não é final nem produtivo, mas que, no entanto, intervém de modo decisivo no crescimento e na produtividade global do trabalho (Pp. 236, 237 e 259, grifo do original).

Consideramos, assim, que o saber local e a comunicação são importantes elementos constituidores dos círculos de informação ascendente; enquanto os círculos de informação descendente estão diretamente relacionados à dotação do território de tecnologias da informação que permitam a chegada desse círculo nas diferentes parcelas das cidades. Essa característica da produção e distribuição da informação hegemônica no território nos permite questionar, com apoio em Santos (2000a [1987]), para que serve a

\footnotetext{
${ }^{8}$ Segundo Santos (1996, p. 238) "esse período se distingue dos anteriores pela profunda interação entre ciência e técnica que vai se dar sob a égide do mercado. Os objetos técnicos tendem a ser também informacionais, já que graças à extrema intencionalidade de sua produção e localização, eles já surgem como informação".
} 
informação? A quem e a quais objetivos ela atende? Já que é necessário dotar o território de técnicas que permitam sua circulação, há então intenções ao se investir capital para tal fim. A informação é uma mercadoria e como tal possui valor, entretanto, trata-se de uma mercadoria não-material, logo, de difícil determinação do valor de troca (GORZ, 2005). Nas palavras de Santos \& Silveira, "Estaríamos autorizados (...) a entender a informação como um recurso, com áreas de abundância e áreas de carência" e, como um recurso, está distribuído de forma desigual pelo território constituindo os espaços luminosos e os espaços opacos.

$\mathrm{Na}$ sequência analisamos como os círculos de informações descendentes, produzido pelas grandes corporações da mídia, tem capacidade de formar uma imagem sobre um lugar e sua população que atenda aos interesses políticos e econômicos dos agentes hegemônicos do processo de globalização.

\section{Informação descendente na região do Jardim Campo Belo9: a mídia a serviço de interesses hegemônicos}

A partir da análise das notícias veiculadas pelo jornal Correio Popular, produzido pela RAC, maior empresa de informação do interior do Estado de São Paulo, notamos que o conteúdo da maioria das manchetes ${ }^{10}$ publicadas, entre 1997 e 2009, sobre a região do Jardim Campo Belo negam uma visão abrangente dos fatos aos cidadãos devido à "tendência a apenas ampliar certos aspectos da realidade, cuja escolha para a exibição pública é com frequência ligada ao mundo da política e dos interesses [hegemônicos]", como afirma Santos (2000a [1987], p. 17).

Observa-se no Quadro 1 abaixo uma síntese dos assuntos noticiados sobre a região, entre os anos de 1997 e 2006. No ano da invasão, em 1997, foram publicadas 4 notícias sobre a região; entre os anos de 1998 e 2005, período no qual a ocupação de estabilizou atingindo um contingente populacional próximo ao atual, ao redor de $50 \mathrm{mil}$ pessoas, foram publicadas apenas duas notícias sobre a área. É nítida a intenção de tornar essa parcela do território e seus moradores invisíveis, silenciar sua existência e seus diversos problemas sociais, quando o principal jornal da cidade passa sete anos sem publicar praticamente nenhuma notícia sobre essa área e seus moradores; e simplesmente

\footnotetext{
${ }^{9}$ Para essa parte da análise exporemos apenas a região do Jardim Campo Belo por passar uma situação bastante emblemática para a discussão trazida nesse artigo. Foi possível constatar uma situação parecida na região do Parque Oziel, porém ultrapassaria o limite de espaço do artigo apresentá-la.

${ }^{10}$ Destacamos as manchetes pois, como é afirmado e descrito por Abramo (2003, p. 23), são elas que mais influenciam na compra dos jornais, logo, na chegada dessas informações à população.
} 
a partir de 2006 até 2009, em quatro anos apenas, são publicadas vinte e nove (29) notícias sobre a região. É possível ainda visualizar nos anexos as manchetes dessas notícias que são, como consta no quadro, majoritariamente desumanizando e criminalizando a população ali residente.

Quadro 1 - Número de notícias sobre a região do Jd. Campo Belo produzidas pela RAC (1997 - 2009)

\begin{tabular}{|c|c|c|}
\hline ANO & $\begin{array}{c}\text { NÚMERO DE } \\
\text { NOTÍCIAS } \\
\text { PUBLICADAS }\end{array}$ & $\begin{array}{c}\text { CONTEÚDO PRINCIPAL DAS } \\
\text { NOTÍCIAS }\end{array}$ \\
\hline 1997 & 4 & Invasão da região do Jd. Campo Belo \\
\hline $1998-2005$ & 2 & $\begin{array}{c}\text { Expansão do aeroporto } \\
\text { Viracopos/Desapropriações no Jd. } \\
\text { Campo Belo }\end{array}$ \\
\hline $2006-2009$ & 29 & $\begin{array}{c}\text { Problemas sociais no Jd. Campo } \\
\text { Belo/Expansão do aeroporto Viracopos/ } \\
\text { Desapropriações }\end{array}$ \\
\hline TOTAL & 35 & \\
\hline
\end{tabular}

Entre os anos de 2006 e 2009 ganha destaque na mídia corporativa brasileira o que foi nomeado por ela própria como ‘caos aéreo' brasileiro após um ‘apagão' nos principais aeroportos do país no início de um feriado prolongado nacional ${ }^{11}$. Nesse período a principal saída encontrada foi a ampliação do Aeroporto Internacional de Viracopos com intuito, inclusive, de torna-lo o maior aeroporto da América Latina, objetivo em andamento atualmente ${ }^{12}$, embora diversos estudos apontassem que não havia necessidade de expandir o aeroporto para atender à demanda existente e em crescimento (CAPPA, 2008).

Para expandir o aeroporto Viracopos seria necessário, então, remover as aproximadamente 7.500 famílias residentes no lugar de maneira irregular e é nesse momento que a mídia corporativa da cidade atende às intenções hegemônicos, afinal o investimento necessário para torna-lo o maior aeroporto da América Latina é de grande escala ainda mais sendo necessário remover esse contingente populacional. O principal jornal da cidade começa a publicar muitas informações sobre essa região e sua população

11 O caos aéreo no Brasil foi deflagrado, no dia 29 de setembro de 2006, devido a acidente no voo da Companhia Gol Linhas Aéreas seguido de diversos problemas operacionais nos meses seguintes.

12 Segundo o Ministério dos Transportes "Viracopos se prepara para ser um dos maiores aeroportos da América Latina" informação publicada no dia 03 fevereiro 2015. <http://www.brasil.gov.br/infraestrutura/2015/02/viracopos-se-prepara-para-ser-um-dos-maioresaeroportos-da-america-latina > Acesso em: 15 mar. 2015. 
que, até então, havia sido silenciada, sem quase nenhuma notícia publicada sobre seus problemas sociais. E nessas publicações, a partir de 2006, o foco das reportagens se voltava para a desumanização dos moradores da área, pois escreviam apenas sobre os assassinatos, o índice de prostituição, a produção e venda de drogas, entre outros elementos, que justificavam moralmente a remoção dessas famílias ${ }^{13}$ para o resto da população. Com isso, a mídia legitimava para as classes abastadas da cidade a necessidade de remover essa população em prol da melhoria do transporte aéreo nacional, como se não houvesse uma alternativa menos desumana ou como esses moradores não merecessem um melhor destino do que voltar para as ruas pois eram 'todos' assassinos e assassinas, prostitutas, vendedores de drogas e assim por diante. Faz-se importante notar que esses fatos realmente aconteciam na região, porém isso só foi afirmado, ainda mais veementemente, pela mídia corporativa quando a área ganhou valor mercadológico.

Como esclarece J. Arbex Jr. no livro de Perseu Abramo (2003, p. 8):

[a 'grande mídia'] é imprescindível como fonte legitimadora das medidas políticas anunciadas pelos governantes e das 'estratégias de mercado' adotadas pelas grandes corporações e pelo capital financeiro. Constrói consensos, educa percepções, produz 'realidades parciais' apresentadas como a totalidade do mundo, mente, distorce os fatos, falsifica, mistifica - atua, enfim, como um 'partido' que, proclamando-se porta-voz e espelho dos 'interesses gerais' da sociedade civil, defende os interesses específicos de seus proprietários privados.

Entretanto, a população se organizou e dificultou o máximo que pode a organização da sua remoção e conseguiu! Junto do Governo Federal, da Infraero e do Governo Municipal foi alterada a área de expansão do aeroporto de Viracopos para uma região rural da cidade onde foi necessário remover 215 famílias da área em oposição às 7.500 que seriam removidas no plano de expansão anterior. É claro que tal alteração se deu não só pela pressão popular, mas também pelos fatores econômicos, pois a remoção dessa grande quantidade de famílias, mesmo que desrespeitando os direitos humanos para ser feita, custaria muito caro por tratar-se de terrenos urbanos e não rurais.

Assim, além da capacidade de manipular a população da cidade, a grande mídia consegue criar uma imagem do lugar até para a própria população ali residente. Quando são veiculadas dezenas de notícias especulando apenas sobre as mazelas de uma região, os próprios moradores da área começam a ter uma visão única do lugar onde moram. Essa perda de compreensão, da complexidade da situação geográfica desses lugares, forma

\footnotetext{
${ }^{13}$ Apresentamos nos anexos tabela com a manchete de todas as notícias contabilizadas no Quadro 1.
} 
cidadãos que não são estimulados a lutar pelos seus direitos, pois cria neles a sensação de merecimento daquela péssima situação de vida e isso é notável ao conversar com essa população nos trabalhos de campo realizados. Como explica Santos (2000b, p. 39)

o que é transmitido à maioria da humanidade é, de fato, uma informação manipulada que, em lugar de esclarecer, confunde. (...) na medida em que o que chega às pessoas, como também às empresas e instituições hegemonizadas, é, já, o resultado de uma manipulação, tal informação se apresenta como ideologia.

Chauí (1990, p. 3) nos explica que “A ideologia (...) é a maneira necessária pela qual os agentes sociais representam para si mesmos o aparecer social, econômico e político (...) é o ocultamento ou a dissimulação do real". Tanto o Estado quanto as corporações da mídia são construtoras e difusoras, assim, de discursos ideológicos. Estes discursos são definidos por esta mesma autora como "aquele que pretende coincidir com as coisas, anular a diferença entre o pensar, o dizer e o ser e, destarte, engendrar uma lógica de identificação que unifique o pensamento, linguagem e realidade para (...) obter (...) a imagem da classe dominante" (ibidem, p. 3).

Por isso, a produção de notícias pela própria população sobre os acontecimentos de seu cotidiano é uma maneira possível de melhorar a compreensão dos moradores sobre o lugar onde vivem de forma que eles se mobilizem para lutar pelos seus direitos. Para analisar essa produção apresentaremos as informações ascendentes encontradas nas duas regiões estudadas.

\section{Produção de informação ascendente na região do Parque Oziel e na região do Jardim Campo Belo}

Nessa análise damos maior ênfase na região do Parque Oziel pois, como já indicamos, essa ocupação fica mais próxima do centro da cidade permitindo um maior acesso às redes de informação e comunicação que perpassam a cidade. Além disso, a proximidade da região do Jardim Campo Belo do aeroporto Viracopos dificulta a implantação de rádios comunitárias ou livres na área, um dos meios de comunicação bastante utilizados nas periferias das grandes cidades e metrópoles brasileiras.

Na região do Jardim Campo Belo analisamos as lan houses $^{14}$ que existem na área e o jornal nomeado 'Folha Vip-Viracopos' veiculado para fins comerciais e produzido pelos próprios moradores da região.

Destacamos a existência das lan houses por serem a principal forma de acesso à

\footnotetext{
${ }^{14}$ Lan houses são os pontos de comércio onde a mercadoria vendida é o acesso ao computador e à internet.
} 
internet na região do Jardim Campo Belo. Lojkine (1995) reflete que o desenvolvimento das Novas Tecnologias da Informação (NTIs), como os computadores pessoais usados nas lan houses, tem como impulso estabelecer conexões densas e interativas entre todos os setores de atividade (idem, p. 229), logo, entre todos os circuitos espaciais produtivos e todos os círculos de cooperação ${ }^{15}$. Os homens criaram e criam constantemente novos usos e objetivos para as NTIs que escapam ao controle dos agentes hegemônicos. Relembramos, como importante exemplo, que o acesso ao sistema de internet denominado como Banda Larga não atinge a Macrorregião Sul de Campinas, ou seja, toda a zona opaca da cidade.

A distribuição pelo território das tecnologias da informação é, como já debatemos, controlada, pois o uso de tais técnicas só é possível com a devida organização do território a partir da instalação das materialidades que permitem a recepção e a difusão das informações. Nas palavras de Lojkine (idem, p. 259) "é extremamente significativa a tessitura financeira dos principais grupos industriais que controlam as infraestruturas urbanas, uma vez que engloba tanto transportes, abastecimento de água, esgotos, quanto fibras óticas, vídeo sistemas de programação e a telecomunicação". Como também esclarece Mattelard (2005), para informar é preciso da instalação das tecnologias da informação, ou seja, de canais que permitam a transmissão da informação, sem a necessidade da existência de laços em comum entre os indivíduos, e, em certa medida, possível de ser controlada sua difusão. E como escreve Santos (2000b) o acesso às técnicas do atual período histórico é um fator indispensável de ser considerado e deve-se buscar os novos usos dados a essas técnicas. O autor ressalta que "o computador, símbolo das técnicas da informação, reclama capitais fixos relativamente pequenos, enquanto seu uso é mais exigente de inteligência (...) e torna-se possível sua adaptação aos mais diversos meios" (idem, p. 164).

As lan houses estão presentes nas principais ruas da região do Jardim Campo Belo e se organizam de diversas formas, embora com algumas características que predominam: tratam-se de fixos de pequeno porte, equipados com até dez computadores conectados à internet e o valor da hora varia de dois a três reais. Os donos desses fixos são moradores

\footnotetext{
15 De acordo com Santos (1999) trata-se dos circuitos da produção material, enquanto os círculos de cooperação compreendem as produções imateriais. Ou seja, as NTIs são um dos mais importantes elementos para a constituição da Produção Flexível, posto que ela permite reduzir o tempo entre os ordenadores do sistema de produção e as linhas de produção que, hoje, se organizam por quase todo o mundo devido, em grande medida, a essa facilidade da troca de informação e do transporte de bens materiais.
} 
da região que usam parte da própria casa para o comércio ou alugam uma casa para esse fim; os computadores são, em geral, máquinas de ‘segunda-mão' compradas por preços inferiores aos do mercado formal. Esses fixos são frequentados principalmente pelos adolescentes e jovens da região em busca de entretenimento, mas o fluxo diário de pessoas não é alto e é difícil de ser definido pelos donos dos estabelecimentos. A recepção do sinal de internet é feita principalmente via rádio, e poucas dessas casas possuem acesso através da tecnologia $3 \mathrm{G}^{16}$.

Dando sequência à análise, um jornal comercial é produzido na região do Jardim Campo Belo intitulado 'Folha Vip-Viracopos'. Neste jornal são publicadas apenas propagandas de comércios da região e há um pequeno classificado, no qual são anunciados terrenos e casas à venda (Figura 01). Há propagandas de outros bairros fora da região do Jardim Campo Belo, porém todos se localizam na Região Sul de Campinas demonstrando a existência de uma densidade comunicacional entre os comerciantes dessa parcela da cidade.

Figura 01 - Título e classificados do jornal produzido pelos comerciantes da região do Jardim Campo Belo (Campinas-SP)

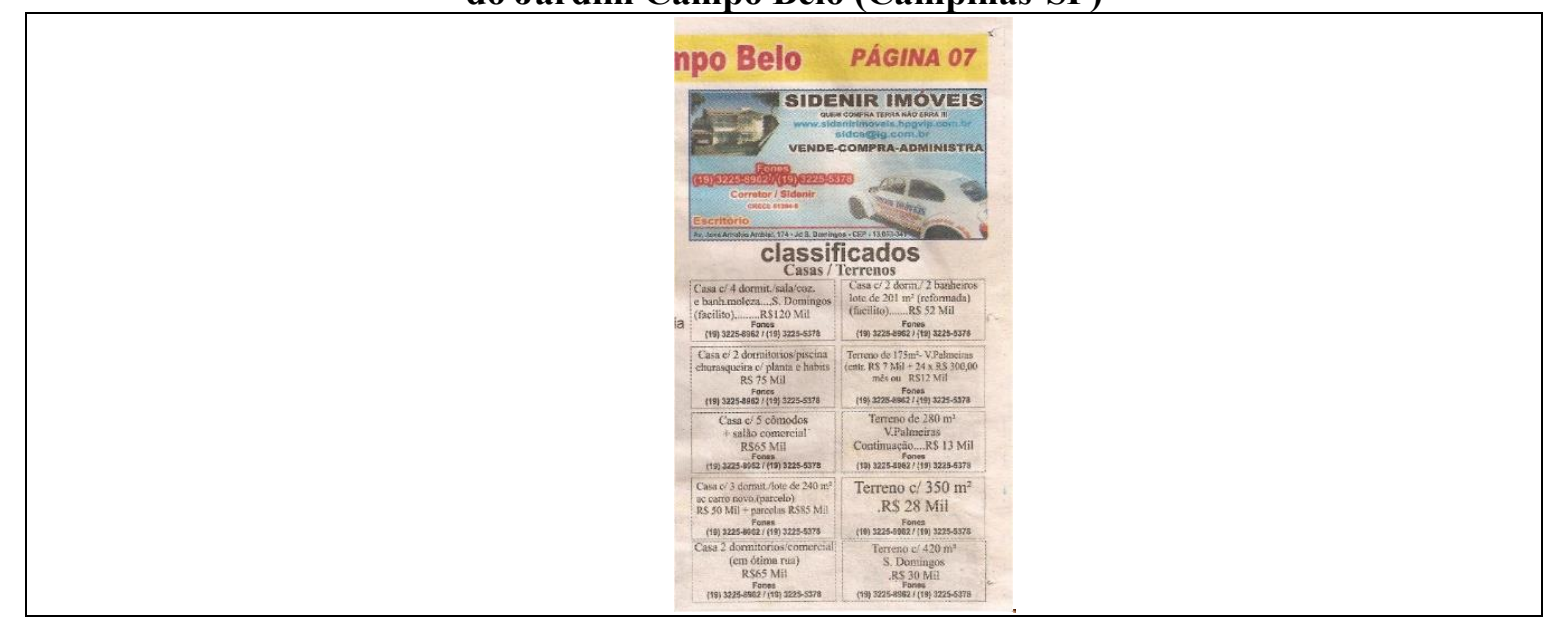

Fonte: Jornal ‘Vip Viracopos’ (2009)

O jornal é organizado pelos comerciantes do lugar, sem uma periodicidade definida na sua publicação. Para financiar essa produção, um grupo de comerciantes fica responsável por arrecadar o dinheiro (cobra-se R $\$ 15,00$ por anúncio) e as propagandas e levá-las para publicação, normalmente em uma gráfica em Campinas. Cada comerciante elabora sua propaganda por diversos meios: alguns pagam terceiros para a elaboração,

\footnotetext{
16 Trata-se da terceira geração $(3 \mathrm{G})$ de tecnologia inventada para o acesso à internet através de objetos móveis (telefone e computador). A primeira foi via rádio criada, na década de 1980, nos Estados Unidos da América; a segunda, criada na década de 1990, foi quando os celulares e outros operadores móveis começaram a utilizar essas tecnologias; e a terceira é a tecnologia que permite acessar a internet ao plugar um aparelho no celular ou no computador que realizará o acesso à rede de internet, essa conexão é feita via instalações de antenas das empresas de comunicação móvel.
} 
outros fazem sozinhos em computadores na própria casa ou do próprio comércio ou, ainda, na casa de conhecidos.

A começar pelo título do jornal notamos certa conformidade com a visão da região construída pela mídia corporativa e pelo poder público municipal que associam a região do Jardim Campo Belo ao aeroporto e às suas dinâmicas, reduzindo o cotidiano dos seus moradores à proximidade desse macrofixo de transporte. Apesar disso, trata-se de uma forma de comunicação produzida através da apropriação das novas tecnologias da informação e é um material organizado pelos moradores do lugar e sobre o lugar. Consideramos um exemplo de informação ascendente que permite compreender um pouco do território onde é produzido e distribuído esse conteúdo informacional alternativo à grande mídia.

$\mathrm{O}$ acesso às tecnologias da informação e a readaptação dessas técnicas ao meio em que são implantadas estão sempre presentes nessas atividades. Sem perder de vista que tudo isso é motivado pelo interesse no consumo, primeiramente remete à luta pela sobrevivência que, por si só, é uma resistência aos interesses hegemônicos da urbanização corporativa de Campinas.

$\mathrm{Na}$ sequência realizamos a mesma análise na região do Parque Oziel onde encontramos dois elementos interessantes: a rádio comunitária Eloy e o jornal Em Destaque ambos produzidas pelo mesmo grupo de pessoas.

A rádio foi montada pelo Sr. João, em agosto de 2002, e começou como segmento evangélico. Porém, segundo o Sr. João pouco tempo depois, a ABRAÇO-Campinas (Associação Brasileiro de Rádios Comunitárias) soube da existência da rádio e entrou em contato com o organizador explicando a importância da rádio ser aberta a todos os tipos de públicos, por se tratar de um importante meio de comunicação e, a partir daí, o Sr. João decidiu abrir a rádio para todos aqueles que quisessem utilizá-la transformando-a de rádio evangélica em rádio comunitária ${ }^{17}$.

\footnotetext{
17 De acordo com Luz (2001) a rádio livre é aquela montada por uma pessoa ou grupo com interesses próprios. Pode ser de esquerda, direita, comercial, anarquista, católica... Foram elas que deflagraram o processo de democratização dos meios de comunicação no país e no mundo. Enquanto a rádio comunitária é uma emissora administrada por um conselho da comunidade, sem fins lucrativos; não pertence a religião, partido ou empresa; seu objetivo maior é o desenvolvimento da comunidade. Conforme a legislação, a rádio comunitária opera em FM. Ela deve ser plural e democrática - tem que abrir espaço para todas as pessoas, todos os partidos, todas as religiões. Não pode fazer proselitismo religioso (propaganda religiosa, catequese). A religião pode pertencer ao conselho comunitário, mas não pode ser a entidade única no conselho, para não caracterizar a propriedade.
} 
O sinal da rádio cobre uma área com raio de dez quilômetros, atingindo principalmente toda a Região Sul de Campinas, sendo transmitida para os bairros ao redor do Parque Oziel como o Jardim São José, o Jardim Itajaí, o Jardim Bandeira e chegando até a região do Jardim Campo Belo atingindo assim toda a Região Sul de Campinas, mas não toda a Macrorregião Sul. A rádio possui um telefone para o público se comunicar com os radialistas demonstrando, para seus organizadores, a receptividade do público em relação aos programas. Ela recebe em torno de setenta ligações por dia e, através dessa participação, também é possível afirmar a existência de ouvintes distribuídos por toda a Região Sul. De acordo com o Sr. João em toda essa área que a rádio consegue atingir não há nenhuma outra rádio comunitária, há apenas algumas de segmento evangélico ${ }^{18}$. Para ele o perímetro atingido pela rádio é suficiente não havendo necessidade de um transmissor de maior potência.

Para a montagem da rádio o Sr. João relatou que não é necessário muito equipamento e o capital inicial investido é baixo. O computador, a mesa de controle e outros objetos mais simples (telefone e tocador de vinil, por exemplo) podem ser comprados na própria cidade de Campinas; e os equipamentos mais especializados, como o transmissor e a antena, são comprados na cidade de São Paulo. Devido aos problemas de legalidade da rádio o transmissor é instalado distante do local de transmissão, atitude recorrente com o desenvolvimento dessa tecnologia chamada 'link de rádio'. A manutenção da rádio é paga via publicidade, ou seja, as pequenas empresas que divulgam vinhetas na rádio pagam um valor que varia bastante de acordo com o horário e o tempo da vinheta.

De acordo com o Sr. João montar uma rádio é fácil, o desafio é fazê-la permanecer existindo devido à ausência de 'material humano' que a alimente. Ou seja, faltam pessoas interessadas em fazer programas na rádio, em ouvi-la, enfim alimentá-la para que permaneça existindo. Nota-se nessa análise do próprio mantenedor da rádio a necessidade de resistência para serem criados e mantidos esses meios de comunicação ascendentes. A constante padronização do que é apresentado pela indústria cultural pode levar ao conformismo das pessoas, de forma que só querem consumir sem a busca pela construção, pela novidade e pela própria fala. Reside aqui um dos elementos mais importantes da

\footnotetext{
${ }^{18}$ Um estudo interessante sobre as rádios da Região Metropolitana de Campinas foi realizado por Alves (2008) onde o autor confirma a maior concentração das rádios livres e comunitárias nas periferias pobres da cidade de Campinas e a predominância do segmento evangélico entre elas.
} 
informação ascendente, a construção do próprio entendimento de mundo e do próprio gosto sendo feita pela população de forma geral, em detrimento do consumo.

Ainda de acordo com o Sr. João, a rádio não sofre muita repressão policial pois é aberta a todos que dela quiserem participar, sejam moradores, políticos, a própria polícia, entre outros. Ele apenas costuma conversar um pouco com os interessados em participar antes de permitir que falem na rádio para ter uma noção de quais são as ideias que pretendem transmitir via espectro eletromagnético, ou seja, pelo ar. Essa constatação, de que a rádio não é reprimida por ser aberta a todos, foi frisada diversas vezes pelo Sr. João e é de grande importância, pois aí reside a principal diferença entre uma rádio comercial e uma rádio comunitária ou livre, as chamadas 'rádios piratas' que sofrem constantemente repressão pela Polícia Federal e Anatel.

Os programadores são voluntários e podem tocar o que quiserem, porém o Sr. João pede a cada programador que tente utilizar um pouco do seu tempo com novidades do mercado, pois se isso não for feito os programadores mantêm apenas o repertório que conhecem sem incluir novidades e a rádio fica defasada com rapidez. Tal defasagem, segundo ele, diminuiria a audiência e a participação da população. A rádio possui uma programação permanente exposta na Foto 02 a seguir.

\section{Foto 02 - Programação da Rádio Eloy em Campinas-SP}

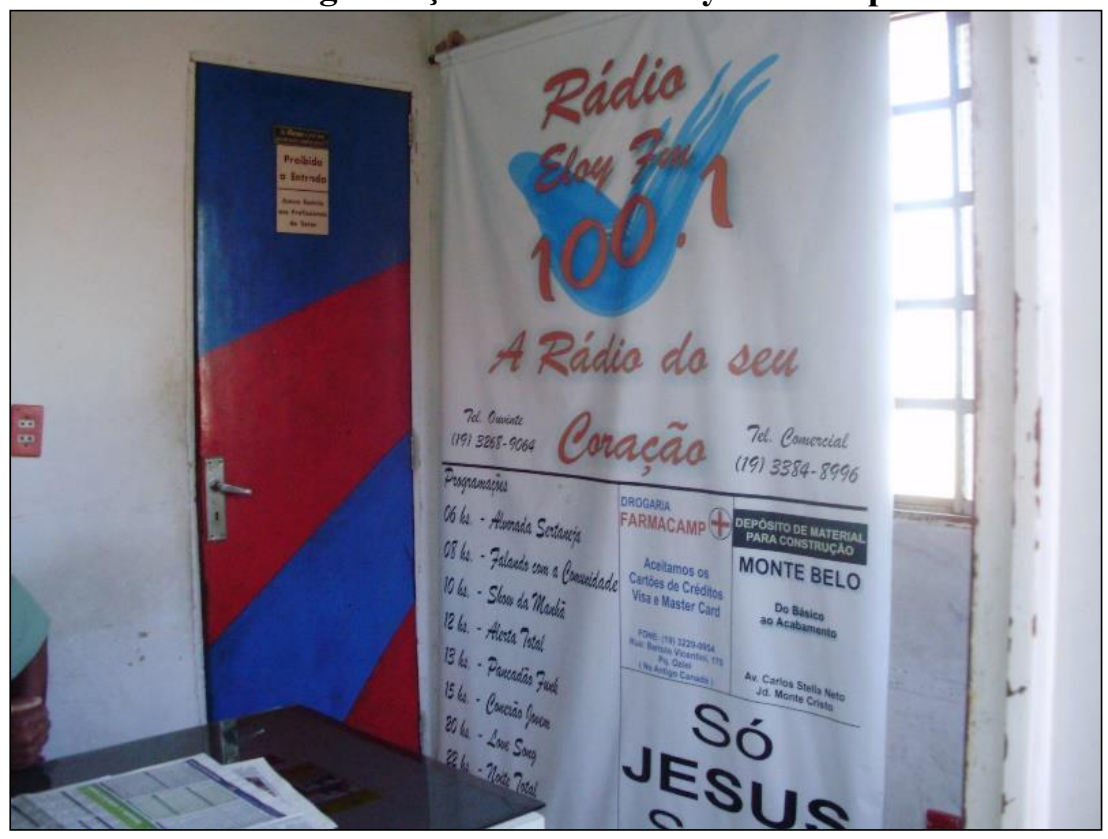

Autoria: autoria própria (2011)

São transmitidos pela rádio, todas as manhãs, os classificados dos jornais da cidade; há também a retransmissão do programa do governo federal "Prosa Rural" enviado pelo mesmo por correio a cada seis meses; são divulgados ainda problemas e 
acontecimentos da região do Parque Oziel e de toda área alcançada pela rádio, como cachorros que são perdidos, documentos encontrados e eventos culturais na região. Notase assim a importância de uma iniciativa de tal natureza para fortalecer a densidade comunicacional da área. A rádio é, portanto, um ponto estratégico do lugar nos momentos de organização de lutas e eventos de grande importância para o cotidiano dessa população.

O Sr. João produz ainda, desde janeiro de 2011, o jornal local nomeado 'Em Destaque'. Os primeiros quatro números foram produzidos apenas por ele com o uso da máquina de impressão de jornal que expomos na fotografia abaixo (Foto 03). Atualmente mais uma pessoa o ajuda a organizar o jornal.

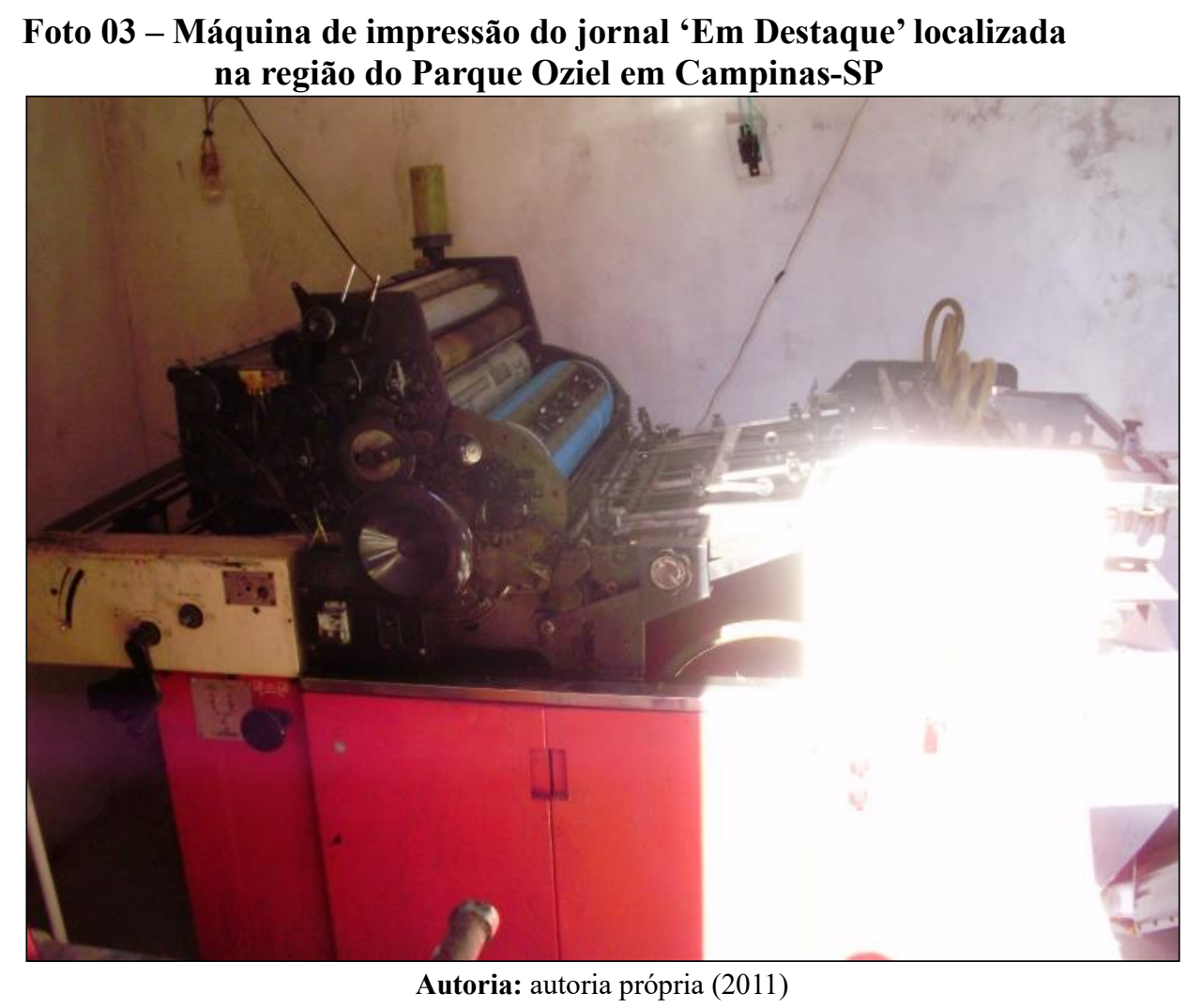

São feitas tiragens de doze mil exemplares que são distribuídas por quase toda a Macrorregião Sul da cidade, e por toda a Região Sul. Essa abrangência do jornal é um fator de grande importância para essa análise, pois indica a área contígua onde se fortalece a densidade comunicacional. Não podemos negar a existência de uma comunicação necessária entre esses bairros, por exemplo, para a distribuição do jornal nos principais estabelecimentos comerciais das diferentes regiões que compõem a Macrorregião Sul; por serem divulgadas notícias e propagandas dos bairros dessa parcela da cidade; entre outras diversas comunicações que precisam ser fomentadas para a produção e distribuição desse material. Apresentamos o expediente do jornal (Figura 04) e algumas notícias e propagandas contidas em um dos números publicados (Figura 05 e 06). 
Figura 04 - Expediente do jornal 'Em Destaque' - Campinas/SP

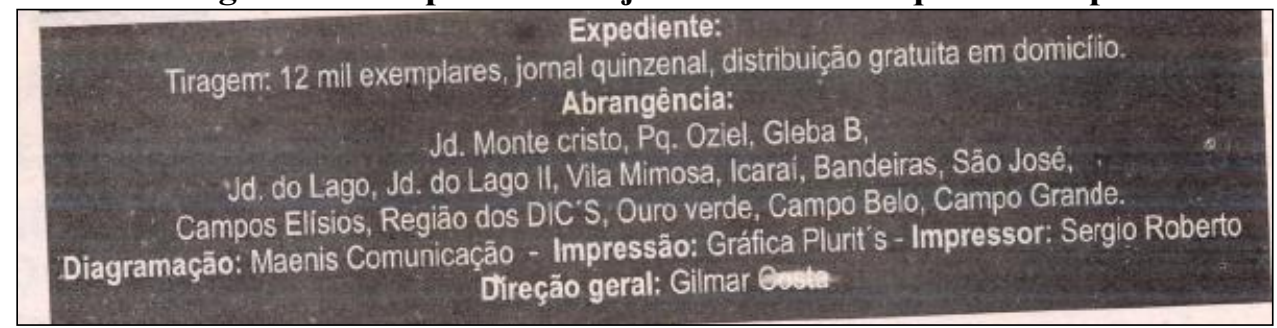

Fonte: Jornal 'Em Destaque’ (2011)

Figura 05 - Notícias dos bairros Jardim Campo Belo e Jardim Bandeira II - Campinas-SP

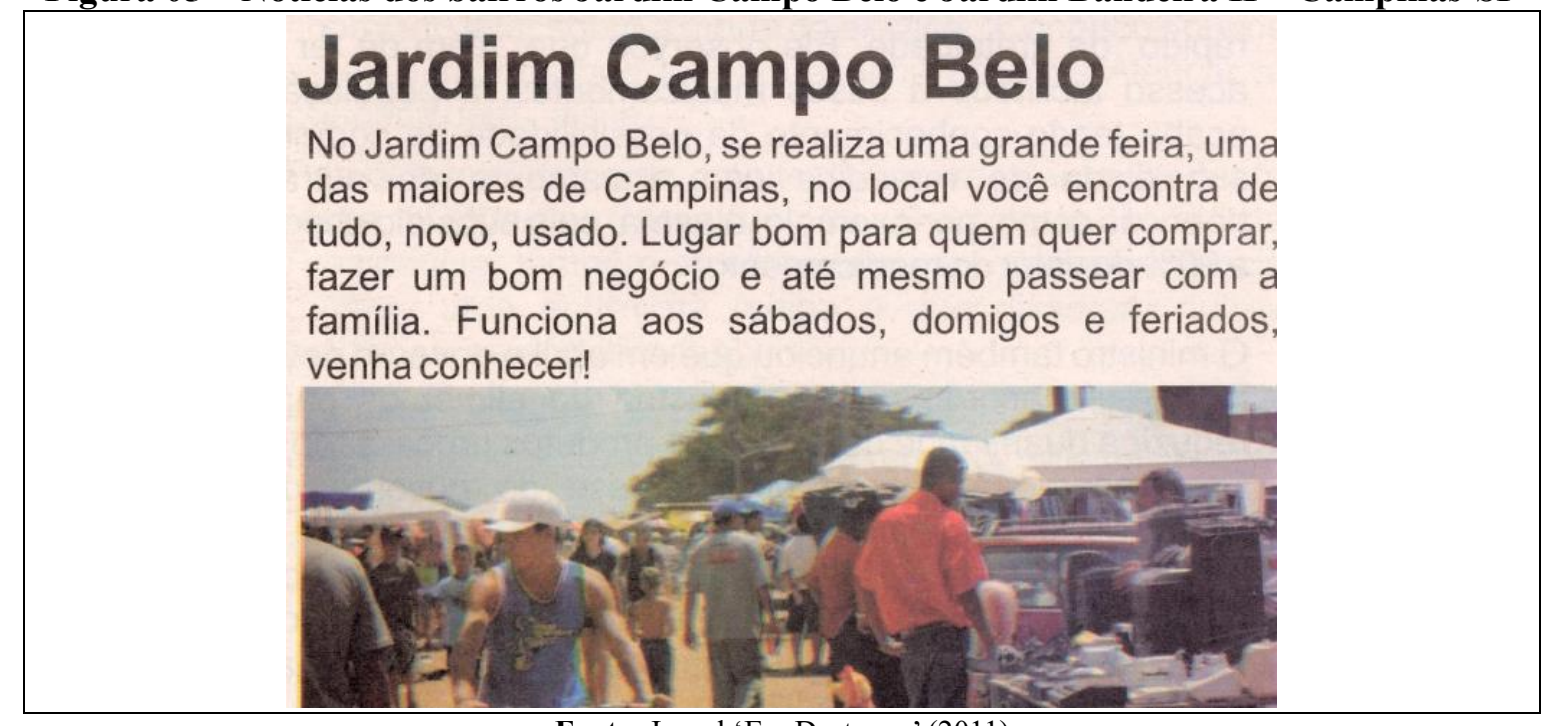

Fonte: Jornal ‘Em Destaque’ (2011)

Figura 06 - Notícia do bairro Jardim Monte Cristo (região do Parque Oziel) - CampinasSP

\section{Jardim Monte Cristo}

Cratera no Monte Cristo à beira da Santos Dumont era uma obra para facilitar a vida dos moradores, mas ao contrario disso, se tornou um problema para quem mora na região. Além de ameaçar a Rodovia e as casas, também se transformou em criadoro de mosquito da dengue e pernilongo. A população reclama pelo descaso, são feitas denúncias mas nada é feito para resolver a situação caótica.

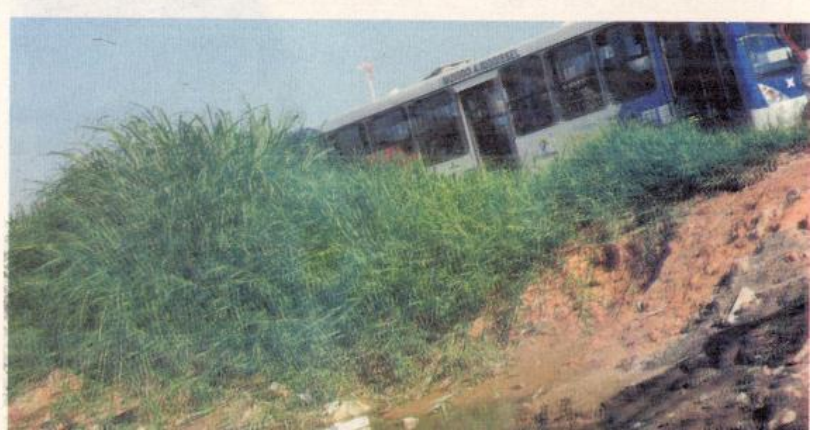

Fonte: Jornal ‘Em Destaque’ (2011) 
A publicação do jornal é custeada através da publicidade, via pagamento de empresários, comerciantes e indústrias para divulgarem suas empresas. $\mathrm{O}$ valor da publicidade varia bastante de acordo com o tamanho e o ponto do jornal em que será exposta. As notícias publicadas são curtas e com informação de diversos tipos: compreendem desde acontecimentos e problemas dos bairros da periferia de Campinas até a reprodução das notícias divulgadas pela mídia corporativa. As mesmas notícias que são publicadas no jornal impresso encontram-se em seu blog: http://jornalemdestaquecampinas.blogspot.com.

Para além da informação veiculada pelo jornal 'Em Destaque', notamos a constituição da densidade comunicacional entre as periferias de Campinas. Trata-se de uma comunicação transmitida entre diversos lugares que não possuem, legalmente, tais vias de troca de conhecimento, saber e informação. Afora o jornal 'Já Notícias' (produzido pela RAC) com material de baixíssima qualidade e pouco informativo, que é distribuído na periferia da cidade valendo-se da precariedade informativa existente nesta parcela do município, não há nenhum incentivo para a existência de canais informativos entre estas frações da cidade; são fragmentos de Campinas que possuem diversas semelhanças, em função de resultarem de intenso processo de periferização e que são superficialmente retratadas e, quando o são, são realizados de maneira perversa e carregada de intencionalidades pelas mídias corporativas como demonstramos no item anterior.

Esse jornal 'Em Destaque' não passa despercebido pelos lugares em que é distribuído, pois, de acordo com os donos de fixos que o distribuem, a população sempre comenta as informações trazidas por eles. Além disso, se a publicidade não surtisse efeito sem dúvida não seria possível bancar uma tiragem de 24 mil exemplares. Concordamos, assim, com a afirmação de Silva (2005, p. 04)

Há um desafio político, que vislumbramos na passagem do período técnicocientífico-informacional ao período popular: produzir informações geograficamente orgânicas e democratizá-las, dando potência à comunicação dos homens lentos (aqueles que vivem no lugar e não apenas circulam); tornarmo-nos sujeitos mais engajados na construção dos lugares em que vivemos.

Como explica também Souza (2006, pp. 261 e 267)

O 'saber local' dos moradores e usuários de um dado bairro formal ou de uma determinada favela pode conter, além de um rico acervo de informações empíricas, tanto ou mais bom senso que a interpretação de um técnico ou estudioso dos problemas urbanos. (...) os ativismos sociais devem procurar gerar seus próprios dados e informações, cooperando entre si (...) para darem lastro e suporte às suas críticas e (contra) propostas; não se devem fiar completamente no aparelho do Estado e dele ficar à mercê para obterem as informações que nortearão sua leitura da realidade. 
E nas palavras de Alves (2014, p. 434) "O saber, a diversidade de experiências e materiais é a riqueza do chamado terceiro mundo, parte de um sistema a margem das decisões políticas e econômicas que culminaram na dinâmica atual do sistema mundo". Possíveis apenas através da resistência e dos novos usos da técnica, constitui-se nessa troca de informações e saberes, nessa vivência à margem da racionalidade sistêmica, nessa comunicação, as contra-racionalidades que indicam a força dos agentes nãohegemônicos.

\section{Conclusão}

Apresentamos nesse artigo como a produção da informação envolve a dimensão do conhecimento técnico e da política, pois além de mercadoria ela é capaz de carregar intenções, objetivos dificilmente compreendidos ao se observar, sem uma sistematização, a maneira como são organizadas e distribuídas. Assim, a desigualdade da implantação das técnicas da informação e da difusão da própria informação no território atende aos interesses dos agentes hegemônicos do processo de globalização. Quando atingimos o lugar, as ocupações de terras urbanas estudadas, nota-se que, apesar da força da urbanização corporativa, da racionalidade, é inegável a força do saber local, da densidade comunicacional e das contra-racionalidades!

Para isso, foram analisadas todas as notícias de jornais publicadas sobre a região do Jardim Campo Belo desde a instalação da ocupação do Jardim Campo Belo, em 1997, até o final do ano de 2010 veiculadas por um importante jornal de Campinas, permitindo, assim, compreendermos de que maneira essas informações descendentes construíram uma imagem do lugar para todos os seus leitores. Buscamos, também, a produção de informação ascendente nessa região e na ocupação do Parque Oziel. Foram encontrados o jornal 'Vip Viracopos' no Jardim Campo Belo, de caráter estritamente publicitário; e, na região do Parque Oziel, o jornal 'Em Destaque' e a 'Rádio Eloi' todos esses veículos foram montados e são mantidos por moradores das regiões.

Enfatizamos, assim, a capacidade da população das duas maiores ocupações de terras urbanas de Campinas de se organizar para viver nesses lugares e, para além disso, produzir informações ascendentes. Demonstra-se tanto a força do saber local quanto a importância da informação no período histórico atual. A densidade comunicacional nesses lugares é uma forma de resistência ao sistema hegemônico, pois permite o acesso a direitos que são espoliados dessa população em prol dos interesses hegemônicos. As 
contra-racionalidades possuem uma grande capacidade de construir a cidade e de permitir a vida e a sobrevivência da população de baixa renda no espaço urbano, como mostramos ocorrer em Campinas

Faz-se necessário, então, que as pesquisas acadêmicas se preocupem em buscar essas resistências e contra-racionalidades difíceis de enxergar no cotidiano das grandes cidades e metrópoles brasileiras se não nos atentarmos a elas com uma metodologia apropriada. Demonstrar que tais ações são tão, ou mais, comuns do que as hegemônicas pode ser um importante passo para alterarmos as políticas públicas e econômicas que engendram uma globalização perversa que priva os direitos humanos à maioria da população residente nesses lugares.

\section{Referências bibliográficas}

ABRAMO, Perseu. Padrões de manipulação na grande imprensa. São Paulo: Fundação Perseu Abramo, 2003.

ALVES, Cristiano Nunes. O circuito sonoro: radiodifusão FM e produção fonográfica em Campinas-SP. 2008. Dissertação (Mestrado) - Departamento de Geografia, Instituto de Geociência, Unicamp, Campinas, 2008.

Densidade comunicativa e a música nos lugares: o circuito sonoro de Recife. XVI Encontro Nacional de Geógrafos, Porto Alegre, 2010. (pp. 09)

Os circuitos e as cenas da música na cidade de Recife: o lugar e a errância sonora. 2014. Tese (Doutorado). - Departamento de Geografia, Instituto de Geociência, Unicamp, Campinas, 2014.

CAPPA, Josmar. Campinas e Viracopos: uma requalificação da metrópole no século XXI. In: SOUZA, M. A. A. (org). A Metrópole e o Futuro: Refletindo sobre Campinas. Campinas: Territorial, 2008. (pp. 157-178)

CHAUÍ, Marilena. Conformismo e resistência: aspectos da cultura popular no Brasil. São Paulo: Brasiliense, 1987.

DANTAS, Marcos. Informação e trabalho no capitalismo contemporâneo. Lua Nova, n. ${ }^{\circ} 60,2003$.

FONSECA, Helena Rizzatti Fonseca. Produção e difusão de informações na cidade de Campinas-SP: um estudo da região do Jardim Campo Belo. 2011. Monografia (Graduação). - Departamento de Geografia, Instituto de Geociência, Unicamp, Campinas, 2011.

GARDINI, André. O território, os meios de comunicação e a produção de informações: a Rede Anhanguera de Comunicação na Região Metropolitana de Campinas. Monografia (Graduação). - Departamento de Geografia, Instituto de Geociência, Unicamp, Campinas,2006.

GONÇALVES, Maria E. Direito da informação. Coimbra: Livraria Almedina, 1994.

GORZ, André. O Imaterial: conhecimento, valor e capital. São Paulo: Annablume, 2005. 
JACOBI, Pedro. Exclusão urbana e lutas pelo direito à moradia. Espaço \& Debates, NERU: Cortez, nº 7, p. 53-69, out./dez., 1982.

LEFEBVRE, Henri. Estrutura social: a reprodução das relações sociais. In.: FORRACHIO, M. M. \& MARTINS, J. S. Sociologia e Sociedade: leituras de introdução à sociologia. São Paulo: Livros técnicos e científicos, 1980.

LOJKINE, Jean. A revolução informacional. São Paulo: Cortez, 1995.

LUZ, Dioclécio. Trilha apaixonada e bem-humorada do que é e de como fazer rádios comunitárias, na intenção de mudar o mundo. Brasília, s.n., 2001.

MATTELARD, Armand. Sociedade do conhecimento e controle da informação e da comunicação. In.: Encontro Latino de Economia Política da Informação, Comunicação e Cultura, V, 2005, Salvador, Conferência conferida ao Encontro Latino de Economia Política da Informação, Comunicação e Cultura, Salvador, s.n., 2005.

RAFFESTIN, Claude. Por uma geografia do poder. São Paulo: Ática, 1993.

RIBEIRO, Ana Clara Torres. Lugares dos saberes: diálogos abertos. In.: BRANDÃO, M. Milton Santos e o Brasil. Território, lugares e saberes. São Paulo: Fundação Perseu Abramo, 2004.

RIZZATTI, Helena. O recente processo de urbanização da cidade de Campinas-SP (1990-2014): as ocupações urbanas - um estudo dos usos do território na Região Sul. 2014. Dissertação (Mestrado) - Departamento de Geografia, Instituto de Geociência, Unicamp, Campinas, 2014.

RODRIGUES, Arlete Moysés. Moradia nas cidades brasileiras. (Tese de Doutorado). São Paulo: Editora Contexto, 1988.

SANTOS, Milton. A natureza do espaço: técnica e tempo, razão e emoção. São Paulo: Hucitec, 1996.

O território e o saber local: algumas características de análise. Cadernos IPPUR, Rio de Janeiro, Ano XIII, n. ${ }^{\circ}$ 2, p.15-26, 1999.

O espaço do cidadão. 5a ed. São Paulo: Nobel, 2000a [1987].

. Por uma outra globalização: do pensando único à consciência universal. São Paulo: Record, 2000b.

A urbanização brasileira. 5a Ed. São Paulo: Hucitec, 2008 [1993].

SANTOS, Milton \& SILVEIRA, María Laura. O Brasil: território e sociedade no início do século XXI. São Paulo: Record, 2001.

SANTOS, Regina Célia Bega dos. Campinas como pólo tecnológico na reestruturação do espaço urbano regional. In: CARLOS, A. F. A.; LEMOS, A. I. G. (Org.). Dilemas Urbanos: Novas Abordagens sobre as Cidades. São Paulo: Editora Contexto, 2000. p. 204-211.

SILVA, Adriana M. Bernardes. A contemporaneidade de São Paulo. Produção de informações e reorganização do território brasileiro. 2001. Tese (Doutorado) Departamento de Geografia, Faculdade de Filosofia Ciência, Letras e Ciências Humanas, USP, São Paulo, 2001.

SILVA, Adriana M. Bernardes. As grandes cidades e o período popular da história. In: SILVA, Maria Auxiliadora, et al. (orgs.) ENCONTRO COM O PENSAMENTO DE MILTON SANTOS, III, 2005, Salvador, O lugar fundamentando o período popular 
da história, s.n., 2005, p. 171-188.

SODRÉ, Muniz. Reinventando a cultura. São Paulo: Vozes, 1996.

SOUZA, Maria Adélia de (org). A Metrópole e o Futuro: Refletindo sobre Campinas. Campinas-SP: Territorial, 2008.

SOUZA, Marcelo Lopes de. A prisão e a ágora: reflexões em torno da democratização do planejamento e da gestão das cidades. Rio de Janeiro: Bertrand Brasil, 2006.

\section{Documentos}

INSTITUTO BRASILEIRO DE GEOGRAFIA E ESTATÍSTICA. Aglomerados Subnormais. Primeiros Resultados. Ministério do Planejamento, Orçamento e Gestão. Censo Demográfico. 2010. Rio de Janeiro, 2011. (p. 1-259)

\section{Anexo}

\begin{tabular}{|c|c|c|}
\hline DATA & MANCHETE DAS REPORTAGENS & FONTE \\
\hline 28/jan/1997 & "Sem-teto invadem terreno no Campo Belo" & Correio Popular \\
\hline 09/jul/1997 & "Sem-teto sobrecarregam sistema elétrico" & Correio Popular \\
\hline 18/jul/1997 & "Sem-teto bloqueiam estrada por duas horas" & Correio Popular \\
\hline 26/out/1997 & "Estrada é fronteira, na linha da miséria" & Correio Popular \\
\hline 22/jul/2001 & "Campo Belo 2 rejeita levantamento" & Diário do Povo \\
\hline $23 /$ fev/2004 & "Região do Campo Belo é a que mais cresce" & Correio Popular \\
\hline $25 / \mathrm{fev} / 2006$ & "Sehac pede a moradores ajuda contra invasões" & Correio Popular \\
\hline 25/jun/2006 & "VIP Viracopos receberá verba de R\$ 74 milhões" & Correio Popular \\
\hline $16 / \mathrm{mar} / 2007$ & "Vip Viracopos: famílias deixarão área de risco" & Correio Popular \\
\hline 06/maio/2007 & "Precariedade põe infância em risco no Campo Belo" & Correio Popular \\
\hline 03/jun/2007 & $\begin{array}{c}\text { "Itaguaçu, mais um nó em Viracopos. Reintegração de posse } \\
\text { concedida há dez anos e que até hoje não foi cumprida expõe dramas } \\
\text { pessoais e sociais na região." }\end{array}$ & Correio Popular \\
\hline 28/maio/2007 & "Infraero começa a pagar indenizações em julho" & Correio Popular \\
\hline 05/ago/2007 & "Invasão limitou Cumbica e Congonhas" & Correio Popular \\
\hline 05/ago/2007 & "Entorno de Viracopos está 'à venda"” & Correio Popular \\
\hline 07/ago/2007 & "Blitz desafina funk no Campo Belo" & Diário do Povo \\
\hline $30 /$ set $/ 2008$ & $\begin{array}{c}\text { "Mulher é espancada e embrulhada em colchão. Os moradores do } \\
\text { Cidade Singer, em Campinas, acordaram assustados com a violência } \\
\text { registrada no bairro." }\end{array}$ & Cosmo Online \\
\hline 29/out/2008 & "Campinas tem 3 casos de homicídios em 24 horas" & Cosmo Online \\
\hline $30 /$ out $/ 2008$ & "Jovem de 16 anos morre em acidente de moto" & Cosmo Online \\
\hline 02/nov/2008 & $\begin{array}{c}\text { "PM prende rapaz com } 89 \text { microtubos com cocaína. Policiais } \\
\text { militares do } 47^{\circ} \text { Batalhão efetuaram a prisão no Jardim Campo Belo 1; } \\
\text { rapaz ainda tinha } \mathrm{R} \$ 300 "\end{array}$ & Cosmo Online \\
\hline 09/nov/2008 & $\begin{array}{l}\text { "Carro com } 5 \text { pessoas e um bebê cai em ribanceira. Moradores do } \\
\text { bairro explicaram que há pelo menos três anos lutam para que no local } \\
\text { seja contruída uma ponte" }\end{array}$ & Cosmo Online \\
\hline 09/nov/2008 & $\begin{array}{c}\text { "Cerca de 40\% dos habitantes vivem em áreas irregulares. Quase } \\
\text { meio milhão de pessoas vivem na informalidade territorial em } \\
\text { Campinas, segundo a Secretaria Municipal." }\end{array}$ & Cosmo Online \\
\hline $10 /$ nov/2008 & $\begin{array}{c}\text { "Veículo que caiu com família em córrego é retirado. A falta de } \\
\text { funcionários no domingo e a demora para uma máquina ser liberada } \\
\text { pela AR-6 foram o motivo do atraso." }\end{array}$ & Cosmo Online \\
\hline $21 / \mathrm{nov} / 2008$ & $\begin{array}{c}\text { "Tiroteio em bar deixa } 3 \text { feridos. Os disparos aconteceram dentro de } \\
\text { um estabelecimento localizado no bairro Jardim Campo Belo 2" }\end{array}$ & Cosmo Online \\
\hline $22 /$ nov/2008 & "Homem é assassinado a tiros no bairro Campituba" & Cosmo Online \\
\hline
\end{tabular}




\begin{tabular}{|c|c|c|}
\hline $23 / \mathrm{dez} / 2008$ & $\begin{array}{c}\text { "Homem é atingido por bala perdida no Campo Belo. Ele foi } \\
\text { levado por equipe do Serviço de Atendimento Móvel de Urgência } \\
\text { (Samu) para o Hospital Ouro Verde." }\end{array}$ & Cosmo Online \\
\hline 09/jan/2009 & "Bairros de Campinas sofrem com período de seca e chuva" & Cosmo Online \\
\hline 09/jan/2009 & "Bairros esquecidos" & Cosmo Online \\
\hline 15/jan/2009 & "Moradores reclamam de buracos na Vl. Palmeiras" & Cosmo Online \\
\hline 24/jan/2009 & "Carga com 68 geladeiras é recuperada no Campo Belo" & Cosmo Online \\
\hline $23 / \mathrm{mar} / 2009$ & $\begin{array}{c}\text { "Invasores de região em Viracopos sairão até } 3^{\text {a }} \text {. O grupo vai } \\
\text { procurar um advogado amanhã para consultar a possibilidade de } \\
\text { reverter a decisão da Justiça." }\end{array}$ & Cosmo Online \\
\hline $23 / \mathrm{abr} / 2009$ & $\begin{array}{c}\text { "Comerciante é executado com } 5 \text { tiros em Campinas. Crime } \\
\text { aconteceu em bar do Jardim Campo Belo 1, na região Sul da cidade; } \\
\text { vítima morava em bairro próximo." }\end{array}$ & Cosmo Online \\
\hline 17/maio/2009 & $\begin{array}{c}\text { "Administração muda a sede para área da AR6. Região Sul recebe } \\
\text { primeira edição do ano da Prefeitura Itinerante." }\end{array}$ & Correio Popular \\
\hline
\end{tabular}


Para citar essa obra:

RIZZATTI, H. A urbanização de Campinas/SP e a produção de informação nas maiores ocupações da cidade In: RUA [online]. $n^{\circ}$. 21. Volume 2, p. 221 - 245 - ISSN 1413-2109. Junho/2015. Consultada no Portal Labeurb - Revista do Laboratório de Estudos Urbanos do Núcleo de Desenvolvimento da Criatividade.

http://www.labeurb.unicamp.br/rua/

Capa: CEDOC/RQAC. Disponível em:

http://correio.rac.com.br/_conteudo/2014/02/capa/campinas_e_rmc/155423-campinasusara-foto-aerea-para-aumentar-arrecadacao.html

Laboratório de Estudos Urbanos - LABEURB

Núcleo de Desenvolvimento da Criatividade - NUDECRI

Universidade Estadual de Campinas - UNICAMP

http://www.labeurb.unicamp.br/

Endereço:

LABEURB - LABORATÓRIO DE ESTUDOS URBANOS

UNICAMP/COCEN / NUDECRI

CAIXA POSTAL 6166

Campinas/SP - Brasil

CEP 13083-892

Fone/ Fax: (19) 3521-7900

Contato: http://www.labeurb.unicamp.br/contato 